\title{
Opcje realne w wycenie aktywów niematerialnych
}

https://doi.org/10.33141/po.2005.03.08

\section{Grzegorz Urbanek}

\section{Wprowadzenie}

$\mathbf{K}$ apitał intelektualny staje się coraz ważniejszym składnikiem wartości wielu firm. Jest to efekt rozwoju „nowej ekonomii”, której pojawienie się jest związane z przesunięciem głównych źródeł tworzenia bogactwa z aktywów materialnych na niematerialne.

W warunkach „nowej ekonomii” efektywność działania wymaga od firm elastyczności i zdolności do tworzenia innowacyjnych strategii. Osiagnięcie tych celów wymaga rozwoju wiedzy i unikatowych umiejętności, które stanowią główny czynnik tworzenia ekonomicznej wartości. W stosunku do tradycyjnych form kapitału, kapitał intelektualny jest trudniejszy do zidentyfikowania, zarządzania i wyceny. Nowe warunki działania wymagają stosowania nowych sposobów zarządzania i pomiaru opartych na wiedzy aktywów.

W rzeczywistości gospodarczej, menedżerowie decydują o inwestycjach na bazie ciągle zmieniających się warunków. Mają oni do wyboru określone możliwości działania, np. podjęcie inwestycji, odłożenie jej w czasie lub zaniechanie. Gdy warunki rynkowe sa wysoce niestabilne, a w decyzjach menedżerskich jest miejsce na elastyczność, tradycyjne metody analizy efektywności podejmowanych działań, oparte na zdyskontowanych przepływach gotówkowych, okazują się niewystarczajace. Ich zastosowanie nie daje gwarancji uzyskania wiarygodnych informacji, umożliwiajacych podejmowanie optymalnych decyzji inwestycyjnych.

Obserwując wycenę rynkową przedsiębiorstw, w szczególności tych, na których działalność wpływ ma wiele niepewnych okoliczności, można zauważyć rosnącą lukę pomiędzy ich wartością rynkową a wartością wynikająca np. ze zdyskontowanych przepływów gotówkowych. Menedżerowie i inwestorzy instynktownie wyczuwają, że wycena rynkowa odzwierciedla zarówno bieżącą pozycję firmy, jak i przyszłe, nieznane obecnie możliwości. Narzędziem, które w wycenie uwzględnia tę dodatkową wartość wynikającą z przyszłych perspektyw i różnych możliwości działania, są opcje realne.

Metody opcji realnych pozwalają na uwzględnienie w wycenach i analizach opłacalności przedsięwzięć rzeczywistych warunków funkcjonowania przedsiębiorstw w „nowej ekonomii”. Celem artykułu jest przedstawienie idei stosowania opcji realnych do wyceny aktywów niematerialnych. Ponieważ tworzenie i wykorzystanie tej kategorii aktywów związane jest
Przegląd Organizacji, Nr 3 (782), 2005, ss. 32-35 www.przegladorganizacji.pl Towarzystwo Naukowe Organizacji i Kierownictwa (TNOiK) z dużą niepewnością, metody opcji realnych są szczególnie przydatne do ich analizy.

\section{Co to są opcje realne?}

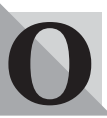

pcje realne wywodzą się z opcji finansowych: call i put. Opcja call daje kupującemu prawo, ale nie obowiązek do zakupu aktywa, którego dotyczy po ustalonej cenie (cena realizacji), w określonym momencie (opcja europejska), lub w dowolnym czasie, do tego momentu (opcja amerykańska). Opcja put daje kupującemu prawo, ale nie obowiązek do sprzedania aktywa po ustalonej cenie, w określonym momencie, lub w dowolnym czasie, do tego momentu.

Opcja realna daje jej właścicielowi prawo do zakupu albo sprzedaży inwestycji w określone aktywa materialne lub niematerialne. Tak więc każda inwestycja, np. w badania i rozwój, patent, marki, szkolenia itp. może stanowić aktyw, na którym określona jest opcja. Zakup marki daje opcję na sprzedaż związanych z nią wyrobów lub usług. Zakup licencji na patent przynosi opcję na jego wykorzystanie w produktach. Inwestycja w badania i rozwój jest opcją call, ponieważ daje możliwość prowadzenia dalszych inwestycji w kolejne fazy rozwojowe.

Opcje realne stanowią uzupełnienie standardowej metody zdyskontowanych przepływów gotówkowych (DCF). Opcje realne korygują wartość uzyskaną w drodze analizy DCF o wartość możliwości podejmowania decyzji adaptacyjnych $\mathrm{w}$ trakcie realizacji projektu. Wyceny metodą DCF i opcji realnych dają różne wyniki, gdy decyzja inwestycyjna (lub jej część) może zostać odłożona w czasie. Odłożenie inwestycji przynosi dwa dodatkowe źródła wartości. Pierwsze, to efekt wartości pieniądza w czasie - lepiej dokonać wydatku później, niż wcześniej. Drugie, to fakt, że okoliczności zewnętrzne mogą ulec w tzw. międzyczasie zmianie, zarówno na korzyść, jak i na niekorzyść firmy. Gdy warunki zmienią się na korzystniejsze, wykorzystanie opcji przyniesie dodatkowe, w stosunku do spodziewanych pierwotnie, efekty. Gdy warunki pogorszą się, rezygnujemy z opcji i tym samym zapobiegamy wydatkowaniu środków na nieopłacalny projekt.

Myślenie w kategoriach opcji realnych opiera się na przesłance, że działania strategiczne często są źródłem nowych opcji. Kiedy zostaną one zidentyfikowane, pozytywnie ocenione i zastosowane, rozpoczynaja nowy cykl kreowania wartości i prowadzą do powstania nowych opcji.

Brian Arthur rozróżnia dwie kultury konkurowania ${ }^{1}$. Tradycyjną - koncentrującą się na optymaliza- 
cji bieżących operacji, gdzie najważniejsze są: planowanie, hierarchia i kontrola. Nowoczesną - opartą na wiedzy, gdzie nacisk położony jest na znajdowanie nowych możliwości. W kulturze tradycyjnej decyzje sa podejmowane na bazie zdyskontowanych przepływów gotówkowych, w kulturze opartej na wiedzy - na bazie wyceny opcji. Można podsumować, że wyższość opcji realnych nad standardowymi metodami oceny wartości (DCF) dotyczy trzech obszarów zagadnień.

- Elastyczność - możliwość odłożenia, porzucenia lub rozszerzenia inwestycji. Przykładowo - firma może odłożyć inwestycję do czasu, gdy uzyska więcej informacji rynkowych. W metodzie DCF wartość takiej inwestycji, a właściwie jej braku, będzie równa zero. W podejściu opcji realnych sama możliwość odłożenia inwestycji będzie miała przypisaną pewną wartość.

- Nowe okoliczności - jest to sytuacja, gdy przyszłe inwestycje są pochodną powodzenia obecnych. Przykładem tego typu sytuacji jest branża farmaceutyczna, gdzie początkowe inwestycje w badania i rozwój w większości kończą się niepowodzeniem. Prowadzą one jednak do osiagania kolejnych faz w rozwoju leków, których pokonanie stwarza nowe okoliczności inwestycyjne. Gdyby przeprowadzić analizę tego typu inwestycji metodą DCF i na bazie otrzymanych wyników podejmować decyzje, prawdopodobnie żadna inwestycja nie zostałaby rozpoczęta.

- Zmienność - w przeciwieństwie do intuicyjnego odczucia, w przypadku dokonywania wyceny metodą opcji realnych, inwestycje charakteryzujące się dużą niepewnością uzyskują wyższą wartość. W standardowym podejściu DCF wyższa niepewność prowadzi do wyższych współczynników dyskontowych i w efekcie do mniejszej wartości bieżącej netto. W opcjach realnych wyższa zmienność prowadzi do większej wartości. Dzięki temu opcje realne pozwalają wycenić aktywa, których wpływ na tworzenie wartości w danym momencie jest trudny do precyzyjnego oszacowania. Oznacza to, że branże opierające działalność na aktywach niematerialnych, które z racji swojej natury charakteryzują się największą niepewnością, mogą korzystać z najbardziej wartościowych opcji.

\section{Opcje realne w aktywach niematerialnych}

A ktywa intelektualne dostarczają firmie wielu opcji, które kierownictwo może elastycznie wykorzystywać w zależności od zaistniałych warunków. Taka elastyczność sama w sobie stanowi źródło wartości, ponieważ daje możliwość unikania decyzji powodujących kumulację zaangażowania w przynoszace straty operacje. Modele opcji realnych dostarczają sposobów na wycenę tych możliwości.

Wartość opcji różnych możliwości działania jest szczególnie ewidentna w branżach chłonnych pod względem inwestycji, oraz w branżach opartych na wiedzy, gdzie proces inwestycyjny w sposób naturalny rozłożony jest na etapy. Podjęcie kolejnego etapu zależy od wyników uzyskanych na etapie poprzednim. Opcje realne mogą znaleźć zastosowanie wszędzie tam, gdzie firmy stoją przed wyborem różnych ścieżek rozwojowych: czy inwestować teraz, czy podjać tylko kroki zapewniajace prawo do dokonania inwestycji w przy- szłości, czy wreszcie nie robić nic? Każdy z tych wyborów kreuje określone rezultaty, połączone z kolejnymi wyborami, w łańcuchu następujących po sobie możliwości.

Opcje realne są szczególnie przydatne w firmach, które charakteryzują się następującymi cechami ${ }^{2}$. Pierwsza, to dobry zarząd, mający reputację na rynku i dzięki temu łatwy dostęp do źródeł finansowania. Takie kierownictwo musi rozumieć, czym są opcje, umieć je identyfikować, tworzyć i stosować. Kolejna, to przywództwo rynkowe - firmy z pozycją lidera maja najwięcej informacji i największe możliwości rozwojowe, chociażby z uwagi na możliwość wykorzystania ekonomiki skali i zasięgu. Wreszcie, opcje realne sa przydatne na rynkach, gdzie częste zmiany są najbardziej ewidentne.

Kluczowym zagadnieniem w wycenie opcji realnych jest określenie momentu wystąpienia i prawdopodobnych poziomów zmienności czynników, które wpływają na wartość projektu. Na bazie tych informacji następuje identyfikacja opcji decyzyjnych. Chociaż opcje realne istnieją w większości biznesów, nie zawsze sa łatwe do znalezienia. Jednym ze sposobów na identyfikację opcji jest analiza projekcji przepływów gotówkowych w poszczególnych okresach. W sytuacji, gdy w dalszym okresie projekcji występuje jednorazowy przepływ ujemny, jest to sygnał możliwości występowania opcji. $\mathrm{Z}$ istnieniem opcji zawsze mamy do czynienia w sytuacji, gdy istnieje możliwość odłożenia inwestycji w czasie.

Opcje realne mogą być sklasyfikowane w następujące główne kategorie:

- opcje wzrostu - możliwość ekspansji w przyszłości, w wyniku podjętych wcześniej działań przygotowawczych,

- opcje odłożenia - możliwość odroczenia inwestycji do czasu zmiany warunków na korzystniejsze,

- opcje rezygnacji - możliwość wycofania się z przedsięwzięcia przed przewidywanym końcem jego realizacji,

- opcje przestawienia - możliwość zmiany profilu lub sposobu produkcji, w zależności od zmian cen surowców, bądź cen wyrobów gotowych.

Wiele aktywów niematerialnych posiada potencjał tworzenia opcji realnych. Dlatego inwestycje w aktywa niematerialne są źródłem opcji związanych z wykreowaniem nowych możliwości rozwojowych w przyszłości, na podstawie stworzonych aktywów. Do działań kreujących nowe możliwości można zaliczyć inwestycje w:

- relacje z partnerami, takie jak:joint ventures, umowy licencyjne, relacje nieformalne, bazy danych;

- zasoby ludzkie, takie jak: szkolenia, trening, kreatywność itp.;

- technologie informatyczne zwiększające zdolność organizacji do uczenia się, wykorzystania wiedzy i stosowania umiejętności;

- tworzenie unikatowej kultury organizacyjnej, która zwiększa jej elastyczność i kreatywność;

- własność intelektualną w postaci: patentów, znaków towarowych, praw autorskich;

- badania i rozwój;

- praktyki i procedury, które ułatwiają identyfikację możliwości wzrostu i eksploatację tych możliwości. 
Inwestycje w wymienione czynniki nie generuja natychmiastowych korzyści. Poniesione wydatki, w większości odnoszone są w koszty, co obniża zysk firmy. Jednocześnie inwestycje te stwarzają możliwości przyszłego rozwoju firmy. Na przykład, inwestycja w bazę danych pozwala na wyselekcjonowanie grupy najbardziej obiecujących klientów. W późniejszym okresie można skierować do nich dodatkowe nakłady, które pozwolą na nawiązanie dochodowych relacji. Jednocześnie posiadanie bazy danych pozwoli na unikanie ponoszenia wydatków na tych klientów, z którymi nie opłaca się współpracować.

Tabela pokazuje wybrane opcje realne, związane z niektórymi czynnikami niematerialnymi.

Do najczęściej stosowanych metod wyceny opcji zaliczają się: model dwumianowy i model Blacka-Scholesa.

Model dwumianowy opisuje zmiany wartości opcji w sytuacji, gdy wartość aktywa, na którym opisana jest opcja, w każdym okresie, przybiera jedną z dwóch możliwych wielkości. Ponieważ opcja reprezentuje prawo, ale nie obowiązek dokonania inwestycji, schemat wypłat jest asymetryczny. Oznacza to, że opcje są wykorzystywane tylko wtedy, gdy ich wartość jest dodatnia. Gdy wartość opcji jest ujemna - nie jest ona wykorzystywana. Rysunek 1 przedstawia możliwe wartości aktywa i wartość opcji po trzech latach.

Jeżeli liczba okresów n zwiększa się do nieskończoności, otrzymane wyniki w modelu dwumianowym sa takie same, jak w modelu Blacka-Scholesa. Model Blacka-Scholesa oparty na teorii opcji finansowych, zmodyfikowanej przez Roberta Mertona ${ }^{3)}$, został zaadoptowany na potrzeby inwestycji w aktywa niefinansowe. Adaptacji powyższego modelu na potrzeby opcji realnych po raz pierwszy dokonał w 1984 roku S. Myers.

W modelu występują następujące czynniki decydujące o wartości opcji:

- wartość bieżąca cash flow związanego z aktywem - (S),

- cena opcji - $(\mathrm{X})$,

- czas opcji - (T),

- dywidenda $(\delta)$ - wartość tracona w czasie trwania opcji (np. koszt utrzymania opcji, cash flow tracony na rzecz konkurentów, którzy zainwestowali w konkurencyjny projekt),

- wolna od ryzyka stopa zwrotu $\left(\mathrm{R}_{\mathrm{f}}\right)$,

- ryzyko związane z aktywem $\left(\delta^{2}\right)$.
Rysunek 2 pokazuje relacje pomiędzy opcją call w modelu opcji finansowych Blacka-Scholesa a realną opcją inwestycyjną.

Wymienione wyżej zmienne stanowią sześć „dźwigni” mogących wpływać na wartość opcji. W przypadku opcji realnych możliwość oddziaływania na ich wartość jest dwutorowa. Po pierwsze, właściciel opcji, w zależności od warunków otoczenia, reaguje w sposób maksymalizujący korzyści, poprzez wybór momentu jej realizacji. Większe efekty można jednak osiągnąć dzięki oddziaływaniu na wymienione wyżej „dźwignie". W przypadku opcji realnych taka możliwość wynika $\mathrm{z}$ faktu, że (inaczej niż ma to miejsce w przypadku opcji finansowych) w ,grę" zaangażowana jest ograniczona liczba podmiotów. W związku z tym każdy z nich jest w stanie wpływać na poziom zmiennych, od których zależna jest wartość opcji. Dlatego menedżerowie powinni wykorzystywać wszystkie możliwości do podwyższenia wartości opcji przed jej realizacją. Zwiększenie wartości opcji może nastąpić dzięki następującym działaniom ${ }^{4}$.

- Podwyższenie wartości bieżącej spodziewanych przepływów gotówkowych, poprzez zwiększenie ceny, zwiększenie sprzedaży ilościowo, lub stworzenie nowych okazji biznesowych.

- Zmniejszenie wartości bieżącej kosztów gotówkowych poprzez wykorzystanie ekonomiki skali (spadek kosztu jednostkowego) lub ekonomiki zasięgu (wykorzystania tego samego kosztu do obsługi różnych dziedzin działania).

- Zwiększenie niepewności spodziewanych przepływów gotówkowych. Większa niepewność powoduje zwiększenie wartości opcji, ponieważ wzrasta elastyczność. W przypadku kupienia opcji firma nie ,stawia na szali" całej kwoty inwestycji i dlatego może skorzystać na wzroście jej wartości, a jednocześnie jest zabezpieczona przed jej spadkiem. Właściciel opcji powinien dążyć do zwiększenia niepewności spodziewanego zwrotu, a następnie starać się „wejść” do gry, gdy sytuacja rozwija się korzystnie, a wycofać się, gdy rozwój sytuacji jest niesprzyjający.

- Wydłużenie okresu „ważności” opcji zwiększa jej wartość poprzez zwiększenie ogólnej niepewności.

- Zmniejszenie wartości utraconej w okresie oczekiwania na realizację opcji. Koszt oczekiwania może być duży w sytuacji, gdy inna firma wejdzie na rynek, którego dotyczy opcja. Utraconą wartość można zmniej-

Tab. Czynniki niematerialne osadzone w opcjach realnych

\begin{tabular}{|l|l|}
\hline \multicolumn{1}{|c|}{ Aktywa niematerialne } & \multicolumn{1}{|c|}{ Rodzaje opcji realnych, które mogą być zastosowane } \\
\hline Badania i rozwój & Opcja odłożenia, opcja rezygnacji, opcja wzrostu - inwestowania w produkcję \\
\hline Patenty & Opcja odłożenia, opcja rezygnacji, opcja wzrostu - inwestowania w produkcję \\
\hline Reklama - marka & $\begin{array}{l}\text { Opcja wzrostu - inwestowanie w produkcję, marketing i sprzedaż } \\
\text { Opcja wzrostu - rozszerzenie marki na nowe produkty }\end{array}$ \\
\hline Systemy informatyczne & Opcje przestawienia \\
\hline Akwizycja technologii & Opcje przestawienia, wzrostu \\
\hline Kapitał ludzki & Opcje wzrostu, opcje przestawienia, opcje odłożenia \\
\hline
\end{tabular}

Źródło: S. SUDARSANAM, G. SORWAR, B. MARR, (2003), Valuation of Intellectual Capital and Real Option Models, paper presented to PMA Intellectual Capital Symposium, 1-2 October, Cranfield University. 

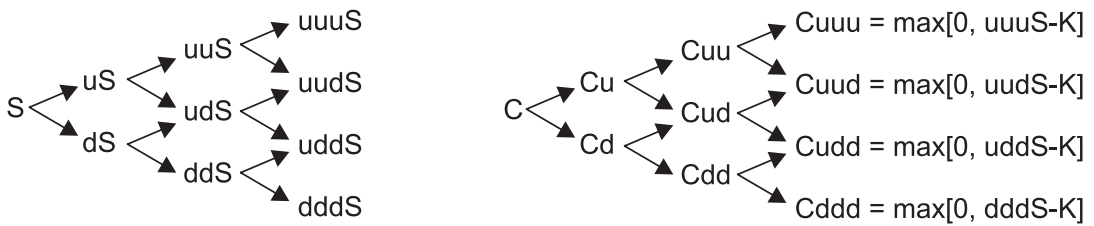

gdzie:

u - zmiana wartości aktywa w górę w jednym okresie,

d - zmiana wartości aktywa w dół w jednym okresie, $\mathrm{K}$ - cena opcji (realizacji)

Rys. 1. Możliwe wartości aktywa (S) i wartość opcji call w trzecim okresie (C)

Możliwość inwestycyjna

\begin{tabular}{|c|}
\hline Wartość bieżąca projektu \\
\hline Koszt realizacji projektu \\
\hline Czas odroczenia decyzji \\
\hline Utracona wartość w okresie opcji \\
\hline Wartość pieniądza w czasie \\
\hline Ryzyko projektu \\
\hline
\end{tabular}

Zmienna

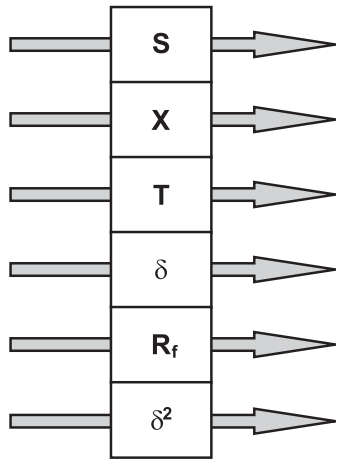

Opcja call

\begin{tabular}{|c|}
\hline Cena akcji \\
\hline Czas realizacji \\
\hline Okres ważności opcji \\
\hline Dywidenda \\
\hline Stopa wolna od ryzyka \\
\hline Zmienność cash flow \\
\hline
\end{tabular}

Rys. 2. Analogie pomiędzy opcją call i opcją realną w modelu Blacka-Scholesa

Źródło: opracowane na podstawie: T. LUEHRMAN, (1998), Investment Opportunities as Real Options, „Harvard Business Review", lipiec-sierpień, s. 52.

szyć, zniechęcając konkurentów do korzystania z ich opcji, np. poprzez przejęcie potencjalnych klientów.

- Zwiększenie stopy zwrotu wolnej od ryzyka leży poza zasięgiem każdego podmiotu. Trzeba jednak pamiętać, że każde zwiększenie stopy zwrotu wolnej od ryzyka zwiększa wartość opcji, ponieważ obniża wartość bieżącą wydatków gotówkowych związanych z projektem.

W modelu Blacka-Scholesa wartość opcji (V) można obliczyć podstawiając dane do następujących wzorów:

$$
V=S e^{(b-r) T} \times N\left(d_{1}\right)-X e^{-r T} \times N\left(d_{2}\right)
$$

gdzie:

$d_{1}=\frac{\ln \left(\frac{S}{X}\right)+\left(b+\frac{\sigma^{2}}{2}\right) \times T}{\sigma \sqrt{T}} \quad d_{2}=d_{1}-\sigma \sqrt{T}$

b - koszt utrzymywania opcji - różnica pomiędzy stopą wolną od ryzyka i stopą dywidendy

$\mathrm{N}(\mathrm{d})$ - skumulowana funkcja rozkładu normalnego

\section{Podsumowanie}

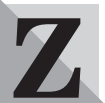
astosowanie modeli opcji realnych może być pomocne w uzasadnianiu inwestycji, które intuicyjnie wydają się korzystne, natomiast których opłacalność wyliczona klasycznymi metodami opartymi na DCF stoi pod znakiem zapytania. $\mathrm{Z}$ tego typu sytuacjami mamy do czynienia w szczególności w przypadku inwestycji w aktywa niematerialne. Inwestycje takie stwarzają liczne przyszłe możliwości rozwojowe, które nie mogą być opisane za pomoca „zwykłych” przepływów gotówkowych.
Mimo swoich zalet, metody wyceny aktywów za pomocą opcji realnych nie są powszechnie stosowane. Autorzy podają dwa najczęstsze powody tego stanu rzeczy. Pierwszy, to wysoki stopień skomplikowania teorii, wymagajacy od użytkownika zaawansowanej wiedzy matematycznej. Drugi, to fakt, że założenia umożliwiające wykorzystanie metod matematycznych, które muszą być przyjęte w niektórych modelach, nie przystają do rzeczywistych warunków. W opinii autora najważniejszą barierą przed stosowaniem modeli opcji realnych jest brak zrozumienia samego mechanizmu tworzenia wartości przez opcję. Problemy obliczeniowe mogą być łatwo rozwiązane poprzez podstawienie konkretnych danych do dostępnych kalkulatorów. Jeżeli chodzi o problem „uproszczenia rzeczywistości” w modelach opcji realnych, to nie jest on większy niż w klasycznych sposobach wycen. Dodatkowo, dzięki odpowiedniemu skonstruowaniu opcji i połaczeniu jej z klasyczną DCF można zbudować model bardzo bliski rzeczywistej sytuacji decyzyjnej.

dr Grzegorz Urbanek Katedra Zarządzania Przedsiębiorstwem Uniwersytet Łódzki

\section{PRZYPISY}

1) Zob. B. ARTHUR, (1996), The New World of Business, „Harvard Business Review”, lipiec-sierpień

2) M. AMRAN, N. KULATILAKA, (1999), Real Options, Harvard Business School Press.

3) Myron Scholes i Robert Merton za swój model uzyskali w 1997 roku nagrodę Nobla. Fischer Black zmarł w 1995 roku.

4) Zob. K. LESLIE, M. MICHAELS, (1997), The Real Power of Real Options, „The McKinsey Quarterly”, nr 3 , s. 97 108. 